每

\title{
Impact of Investment, Labor, and Infrastructure on Java Island Economic Growth 2011-2017
}

\author{
Maya Aprilia Sari \\ Jurusan Ekonomi Pembangunan, Fakultas Ekonomi, Universitas Negeri Semarang \\ Permalink/DOI: https://doi.org/10.15294/efficient.vii3.35151
}

Received: Juny 2018 ; Accepted: September 2018 ; Published: December 2018

\begin{abstract}
The study aims to determine and analyze the effect of investment, labor, and infrastructure on economic growth in Java in 2011-2017. This research is a quantitative study using secondary data from six provinces in Java (DKI Jakarta, West Java, Central Java, Special Region of Yogyakarta, East Java and Banten) obtained from the Central Statistics Agency. Analysis of the data used in this study is panel regression of fixed effect model data using the General Least Square (GLS) method. The results showed that individually the domestic investment variable, labor, clean water infrastructure had a significant influence on economic growth while foreign investment had no significant effect on economic growth. Suggestions: 1) local governments are expected to increase the potential of each region to attract investors; 2) local governments are expected to create a conducive investment climate and facilitate investment licensing; 3 ) local governments are expected to increase the allocation of education funds and provide training in foreign languages and skills to the workforce; 4) local governments should make better plans for the distribution of clean water and improve the efficiency of the use of clean water.
\end{abstract}

\section{Keywords: Investment, Labor, Infrastructure, Economic Growth}

\begin{abstract}
Abstrak
Penelitian bertujuan untuk mengetahui dan menganalisis pengaruh investasi,tenaga kerja, dan infrastruktur terhadap pertumbuhan ekonomi di Pulau Jawa tahun 2011-2017. Penelitian ini merupakan penelitian kuantitatif menggunakan data sekunder enam provinsi di Pulau Jawa (DKI Jakarta, Jawa Barat, Jawa Tengah, Daerah Istimewa Yogyakarta, Jawa Timur, dan Banten) yang diperoleh dari Badan Pusat Statistik.Analisis data yang digunakan pada penelitian ini adalah regresi data panel model fixed effect menggunakan metode General Least Square (GLS). Hasil penelitian menunjukkan bahwa secara individu variabel penanaman modal dalam negeri, tenaga kerja, infrastruktur air bersih memiliki pengaruh signifikanterhadap pertumbuhan ekonomi sedangkanpenanaman modal luar negeri tidak berpengaruh signifikan terhadap pertumbuhan ekonomi. Saran: 1) pemerintah daerah diharapkan meningkatkan potensi setiap daerah agar menarik para investor; 2) pemerintah daerah diharapkan menciptakan iklim investasi yang kondusif dan mempermudah perizinan investasi; 3 ) pemerintah daerah diharapkan meningkatkan alokasi dana pendidikan dan memberikan pelatihan bahasa asing dan ketrampilan kepada tenaga kerja; 4) pemerintah daerah hendaknya membuat perencanaan distribusi air bersih yang lebih baik lagi dan meningkatkan efisiensi penggunaan air bersih.
\end{abstract}

Kata Kunci: Investasi, Tenaga Kerja, Infrastruktur, Pertumbuhan Ekonomi

How to Cite: Sari, M. (2019). IMPACT OF INVESTMENT, LABOR, AND INFRASTRUCTURE ON JAVA ISLAND ECONOMIC GROWTH 2011-2017. Efficient: Indonesian Journal of Development Economics, 1(3), $230-241$. https://doi.org/10.15294/efficient.vii3.35151

(C) 2019 Semarang State University. All rights reserved

Alamat Korespondensi :

Alamat: Gedung L2 Lantai 2 FE Unnes

ISSN 2655-6197

Kampus Sekaran, Gunungpati, Semarang, 50229

E-mail : efficientjournal@gmail.com 


\section{INTRODUCTION}

Economic growth is an economic development that causes the production of goods and services to increase in community economic activity as measured by an increase in production output and income (Sukirno, 2002). Economic growth is also one indicator used to measure the performance of an economy.

High economic growth is the main goal for the economy because the higher economic growth will certainly encourage economic development both regionally and national is getting faster. Economic growth can be measured using Gross Domestic Product (GDP) and for the regional scope using Gross Regional Domestic Product (GRDP).

Indonesia is an archipelago consisting of five large islands namely Java, Sumatra, Sulawesi, Kalimantan, Maluku-Papua, and one small island, namely Bali-Nusa Tenggara. The GDP contribution of the six islands certainly has an important role to play in the formation of GDP in Indonesia. Data on GDP contribution to GDP by island in Indonesia can be seen in table 1

Table 1. Contribution of GRDP to GDP Formation by Island in Indonesia in 2011-2017 (percent)

\begin{tabular}{llllllll}
\hline \multirow{2}{*}{ Island } & \multicolumn{7}{c}{ Year } \\
\cline { 2 - 8 } & 2011 & $\mathbf{2 0 1 2}$ & $\mathbf{2 0 1 3}$ & $\mathbf{2 0 1 4}$ & $\mathbf{2 0 1 5}$ & $\mathbf{2 0 1 6}$ & $\mathbf{2 0 1 7}$ \\
\hline Sumatera & $\mathbf{2 2 , 8 7}$ & $\mathbf{2 3 , 7 7}$ & $\mathbf{2 3 , 8 1}$ & $\mathbf{2 3 , 6 3}$ & $\mathbf{2 2 , 2 1}$ & $\mathbf{2 2 , 0 2}$ & $\mathbf{2 1 , 6 6}$ \\
Jawa & 56,69 & 57,62 & 57,99 & 58,51 & 58,29 & 58,40 & 58,49 \\
Bali-Nusa Tenggara & $\mathbf{2 , 8 3}$ & $\mathbf{2 , 5 1}$ & $\mathbf{2 , 5 3}$ & $\mathbf{2 , 5 0}$ & 3,06 & 3,18 & 3,11 \\
Kalimantan & 9,92 & 9,30 & 8,67 & 8,21 & 8,15 & 7,72 & 8,20 \\
Sulawesi & 5,23 & 4,74 & 4,82 & 4,97 & 5,92 & 6,15 & 6,11 \\
Maluku-Papua & $\mathbf{2 , 4 4}$ & $\mathbf{2 , 0 6}$ & $\mathbf{2 , 1 8}$ & $\mathbf{2 , 1 8}$ & $\mathbf{2 , 3 7}$ & $\mathbf{2 , 5 3}$ & $\mathbf{2 , 4 3}$ \\
\hline
\end{tabular}

Source: Statistics Indonesia, 2012-2018

Based on table 1 it can be seen that the island of Java as the largest contributor to GDP in the formation of GDP in Indonesia compared to the other five islands. Java's GRDP in 2011 contributed $56.69 \%$ to Indonesia's GDP, although there was a decline in 2011 and 2015 but the contribution of Java's GRDP tends to increase. Java's GRDP contributes more than half of Indonesia's GDP, this is because economic activity in Indonesia is centered on Java, making Java as the economic magnet in Indonesia and has the largest PDRB contribution to Indonesia's GDP. Sumatra Island is the island with the largest
PDRB contribution after Java. In 2011 the contribution of Sumatra Island amounted to $22.87 \%$ and continued to increase until 2013 to $23.81 \%$ but in 2014 the contribution of Sumatra Island's GRDP began to decline until in 2017 it became $21.66 \%$. Then, the province with the lowest PDRB contribution is occupied by Maluku-Papua Island whose contribution to Indonesia's GDP is only around $2 \%$.

The success of the island of Java as the largest contributor to the GRDP contribution to Indonesia's GDP certainly cannot be separated from the development carried out by the six provinces in Java that took place 
thoroughly and continuously so as to improve the economy.

Table 2. GRDP Based on 2010 Constant Prices by Province in Java in 2011-2017 (billion rupiah)

\begin{tabular}{lllllll}
\hline \multirow{2}{*}{ Year } & DKI Jakarta & Jawa Barat & Jawa Tengah & DIY & Jawa Timur & Banten \\
\hline 2011 & 1.147 .558 & 965.622 & 656.268 & 68.050 & 1.054 .402 & 290.546 \\
2012 & 1.222 .528 & 1.028 .410 & 691.343 & 71.702 & 1.124 .465 & 310.386 \\
2013 & 1.296 .695 & 1.093 .544 & 726.655 & 75.627 & 1.192 .790 & 331.099 \\
2014 & 1.373 .389 & 1.149 .216 & 764.959 & 79.536 & 1.262 .684 & 349.351 \\
2015 & 1.454 .564 & 1.207 .232 & 806.765 & 83.474 & 1.331 .376 & 368.377 \\
2016 & 1.540 .078 & 1.275 .528 & 849.313 & 87.688 & 1.405 .561 & 387.824 \\
2017 & 1.635 .856 & 1.342 .953 & 894.050 & 92.301 & 1.482 .148 & 409.960 \\
\hline
\end{tabular}

Source: Statistics Indonesia, 2012-2018

Based on table 2 it can be seen that the sixth province's GRDP in Java has increased every year. DKI Jakarta Province has the largest PDRB value of $1,147,558$ billion rupiah in 2011 and has always experienced an increase until 2017 amounting to $1,635,856$ billion rupiah. DKI Jakarta as the capital city of Indonesia, of course, has high economic activity so that it has the highest PDRB value in Java. The Special Region of Yogyakarta has the lowest PDRB value in Java, amounting to 68,050 billion rupiah in 2011, although it occupies the lowest position but the Special Regional GDP value Yogyakarta continues to increase every year. Each province must have different GRDP values because each province has different policies in encouraging regional development to adjust the strengths and weaknesses of each province. A high GDP value is not always followed by a high rate of economic growth, currently economic growth is still a serious problem in various regions in Indonesia including Java. According to the Central Bureau of Statistics for economic growth, the island of Java declined. The following rate of economic growth in Java can be seen in Figure 1.

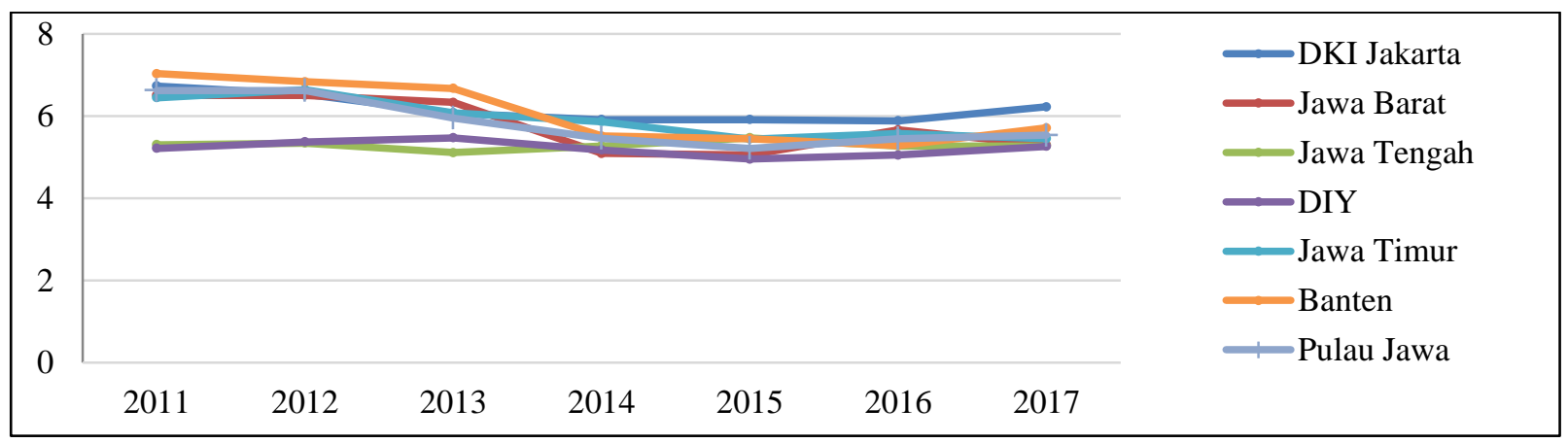

Figure 1 GRDP Rate of Constant 2010 Prices by Province in Java in 2011-2017 (percent) Source: Statistics Indonesia, 2012-2018 
Based on Figure 1 it can be seen that the economic growth of Java Island is decreasing. In 2011-2012 the economic growth of Java Island experienced a stagnation of $6.02 \%$ and decreased in 2013-2015 where in 2013 the economic growth of Java Island was 5.95\% lower $0.07 \%$ compared to 2012 which was $6.02 \%$. In 2014, from $5.46 \%$ it was down $0.49 \%$ from the previous year which was $5.95 \%$, then in 2015 from $5.21 \%$ it was down by $0.25 \%$ when compared to the previous year which was 5.46\%. Although in 2016 and 2017 the economic growth of Java Island has increased but the rate of economic growth is not as fast as in previous years.

The economic growth of the island of Java which is declining if it happens continuously will be a big problem. Considering that Java Island is the biggest contributor to the GRDP of Indonesia's GDP, economic growth in Java has an important role in national economic growth. Despite these problems, there are still a number of provinces in Java whose economic growth is below the national average of $5 \cdot 52 \%$, namely Central Java and Yogyakarta Special Region.

Economic growth consists of three factors, namely capital accumulation, labor and technological progress (Todaro, 2000). Based on the Harrod Domar growth model so that economic growth is encouraged, a new investment is needed. One way for the government to encourage economic growth in the, long run, is to increase investment (Mankiw, 2003). Java's Domestic Investment (PMDN) is still fluctuating. Realization of Domestic Investment (PMDN) in Java can be seen in Figure 2

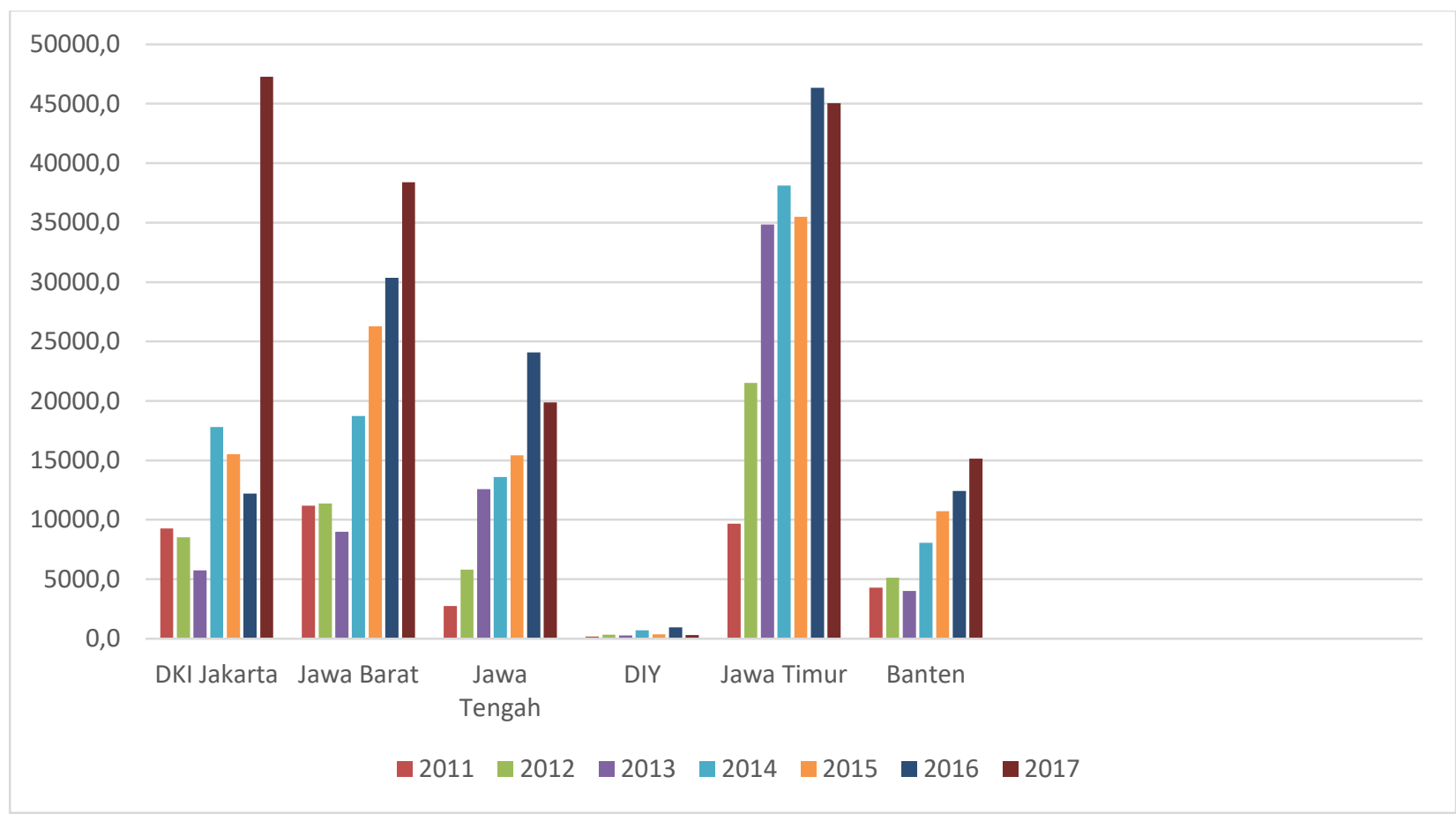

Figure 2. Realization of Domestic Investment by Province in Java in 2011-2017 (billion rupiah) Source: Statistics Indonesia, 2012-2018 
Based on Figure 2 it can be seen that the Domestic Investment (PMDN) of the six provinces in Java is still experiencing fluctuations. The largest domestic investment realization (PMDN) was East Java Province, where the average investment realization in East Java was 27,457.96 billion rupiah. West Java is a province withthe average Domestic Investment (PMDN) is the largest after East
Java which has an average Domestic Investment (PMDN) of 20,762.1 billion rupiah.

The Special Region of Yogyakarta has the lowest average Domestic Investment (PMDN) value in Java, which is 439.73 billion rupiah. Besides addition to Domestic Investment (PMDN), data on the realization of Foreign Investment (PMLN) of Java Island can be seen in figure 3

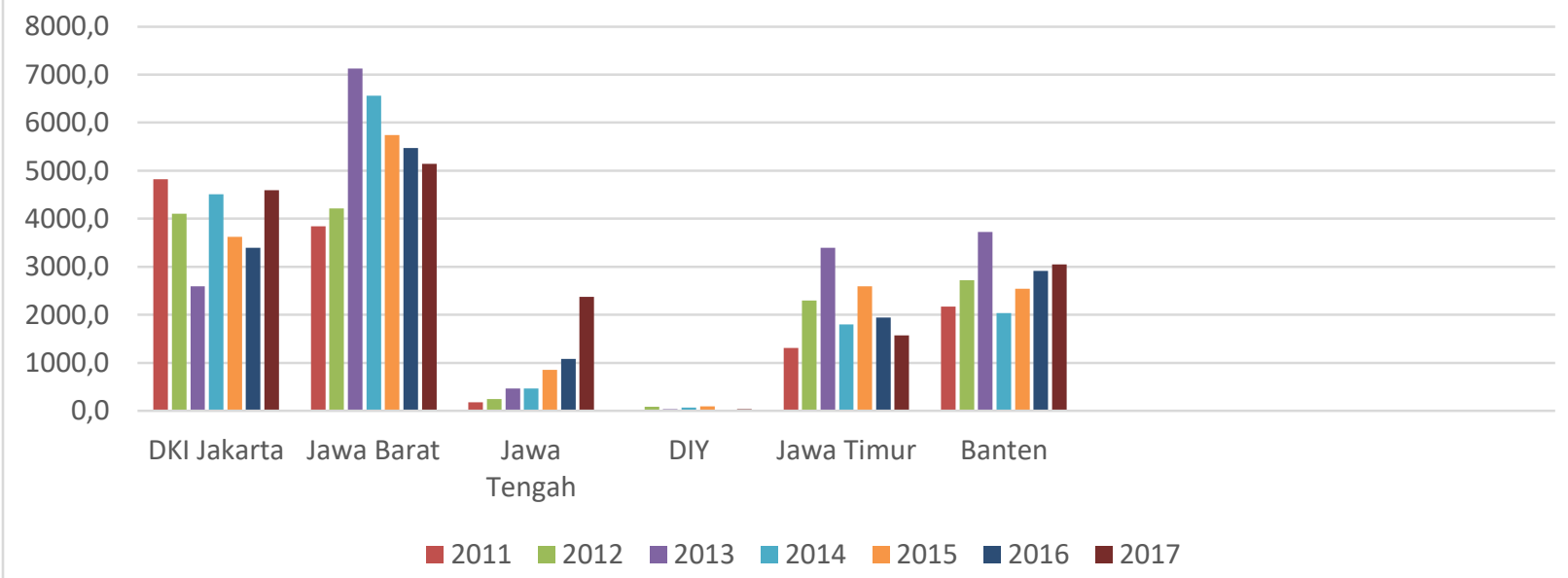

Figure 3. Realization of Foreign Investment (PMLN) by Provincein Java in 2011-2017 (million US \$) Source: Statistics Indonesia, 2012-2018

Based on Figure 3 it can be seen that the realization of Foreign Direct Investment (PMLN) has also fluctuated. The largest foreign investment realization (PMLN) in Java is West Java Province. The average investment realization in West Java is 972.69 million US \$ while the lowest average is in Yogyakarta Special Region which is 41.49 million US \$.

Investment is one of the first steps to carry out a development. Based on the explanation above it can be seen that there is still an investment imbalance in Java, if comparing the provinces with the highest average investment with the lowest one has a very large difference. Investment in both Domestic Investment (PMDN) and Foreign Investment (PMLN) in Java is currently still concentrated in East Java and West Java Provinces. Investment disparity between provinces is certainly not good if it occurs continuously because other provinces also need to be invested in capital in order to keep up with the economic growth of other provinces. Human resources also become an important development capital besides investment (Todaro, 2004). Labor is a factor that affects the economic growth of a 
region because the more labor the higher the productivity, so that it can encourage regional economic growth. The number of workers in several provinces in Java is still experiencing fluctuations.

Large population growth will form a large workforce. Sukirno (2011) argues that population growth will be a problem for economic growth because population growth will actually hamper the economic growth of a country or region whose economy is not yet high. The large population on one side will form a large workforce but, on the other hand, a large population growth if not followed by employment opportunities will only hamper economic growth. In addition, an increase in labor quantity is meaningless if it is not balanced with the quality of the workforce.

The availability of infrastructure is also one of the important factors, infrastructure as a driving wheel of the economy certainly has a vital role in the economic development of a region because development cannot run smoothly if a facility and infrastructure are not good.

Todaro (2000) argues that to improve the economy, it must be equipped with various supporting facilities, namely infrastructure such as roads, electricity, water supply, and sanitation improvements, communication network development. The availability of clean water infrastructure has an important role to play in economic growth. The lack of clean water availability can hamper the economy because the production process cannot be separated from clean water infrastructure, so clean water also needs to be one of the priorities in development.

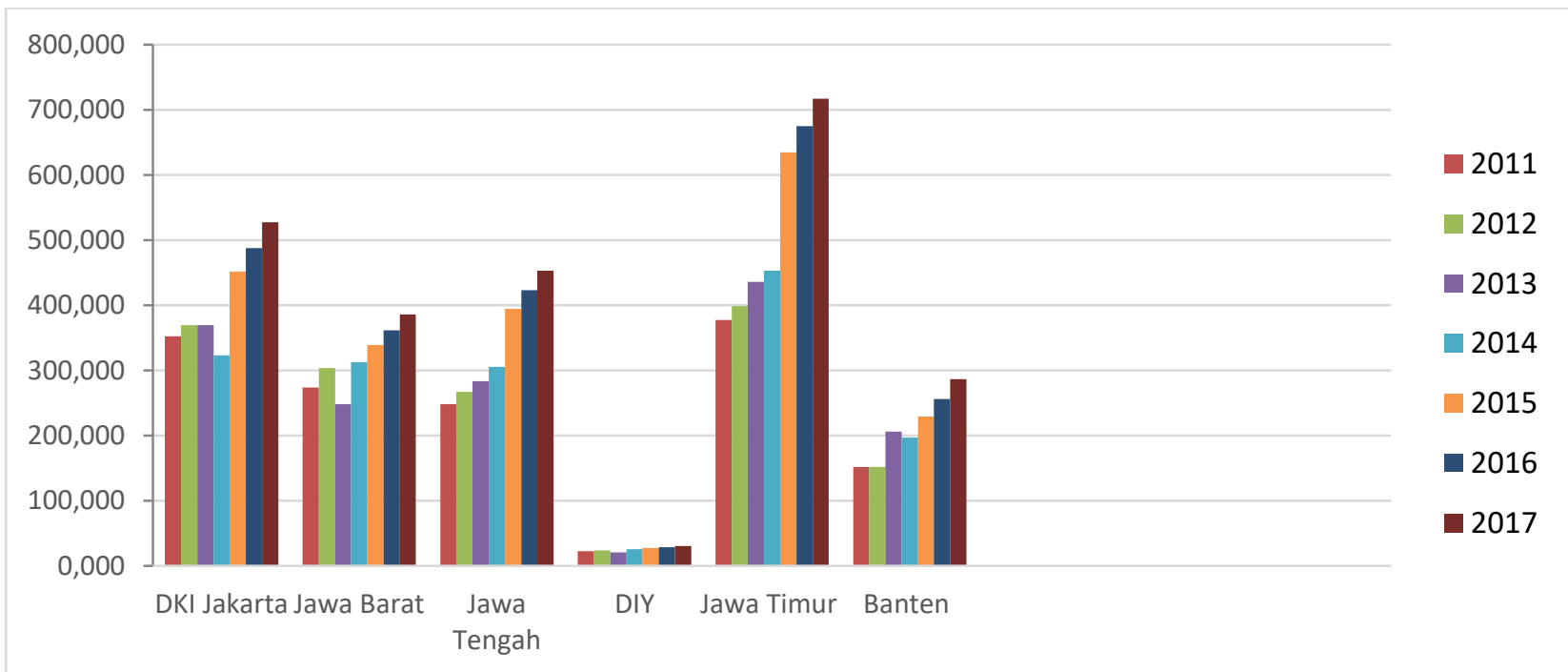

Figure 4. Distribution of Clean Water by Province in Java in 2011-2017 (thousand $\mathrm{m}_{3}$ ) Source: Statistics Indonesia, 2012-2018

Based on figure 4 it can be seen that the distribution of clean water in Java is still experiencing fluctuations. The distribution of clean water held by clean water companies is still uneven, this indicates that there is still an imbalance in the use of clean water in each 
region. Clean water infrastructure has an important role both in meeting daily needs and for economic activities so that, if there is still an imbalance it will certainly interfere, especially for the production process which will affect economic activities.

The highest distribution of clean water is East Java Province wherein 2017 it reached 716,836 thousand $\mathrm{m} 3$ while the distribution of clean water in West Java was only 386,065 thousand $\mathrm{m}_{3}$ whereas West Java was the region with the largest population and West Java was the largest industrial area on the island of Java. This indicates that the need for clean water in West Java should be greater than East Java. The imbalance between the distribution of clean water with the population and the number of industries will certainly affect the results of production which will lead to regional economic growth.

There are several studies linking clean water infrastructure to economic growth, but it is still a debate. Rusmusi and Handayani (2018) found that clean water infrastructure had a significant effect and had a positive relationship. In contrast to Dewi and Gusni (2019) who found that clean water infrastructure had no significant effect and had a negative relationship on economic growth. Differences in these findings are still being debated, so there is a need for further study on this matter.

Based on this background, several research questions can be formulated. (1) What is the effect of domestic investment on economic growth? (2) What is the effect of foreign investment on economic growth? (3) What is the effect of labor on economic growth? (4) What is the effect of clean water infrastructure on economic growth?

The purpose of this study is to identify and analyze: (1) The effect of domestic investment on economic growth. (2) The effect of foreign investment on economic growth. (3) The effect of labor on economic growth. (4) The effect of clean water infrastructure on economic growth.

The theory of economic growth explains what factors influence economic growth. There are several theories of economic growth including classical economic growth theory, one of the figures of the classical economist is Adam Smith. Adam Smith explained that the core of the process of economic growth is divided into two main aspects, namely total output growth and population growth. Output Growth A country's national production system consists of three main elements, namely natural resources (land production factors), human resources (population), available capital stock.

Furthermore, the economic growth model included in the neo-Keynesian economic growth theory is the Harrod-Domar economic growth model. The Harrod-Domar economic growth model was developed by Evsey D.Domar and Roy F. Harrod. This Harrod-Domar economic growth model is a development of Keynes's macro theory of macroeconomics in the long run by including the role of investment (I), where HarrodDomar explains that investment (I) not only has an influence on aggregate demand (AD) but also influence the aggregative supply (US) through its influence on production capacity (Prasetyo, 2009). Private investment in Indonesia is guaranteed to exist as stated in 
Law No. 25 of 2007 divides investment into two forms, namely domestic investment and foreign investment.

Neoclassical economic growth models are often referred to as modern theories especially after the emergence of the SolowSwan growth model known as the New Growth Theory. The Solow-Swan growth model focuses more on how population growth, capital accumulation, technological progress, and output interact with one another in a process of economic growth.

Referring to the Sollow-Swan theory that in increasing economic growth, it is necessary to have a stock of capital where the intended stock of capital is not only the stock of human capital but also the stock of physical capital. The intended physical capital stock is infrastructure. Infrastructure is a public facility that is physical in the form of roads, buildings, bridges, transportation, and other public facilities. Infrastructure as the main support in social and economic development in daily life for the community. The availability of infrastructure is also one of the important factors as a driver of the economy.

According to the World Bank (1994) Infrastructure is divided into three, consisting of: (1) Economic infrastructure is physical development that supports economic activities including public utilities (Telkom, water, sanitation, electricity, gas), public work (dams, roads, irrigation, drainage and canals) as well as the transportation sector (roads, rail ports, airports, etc.). (2) Social infrastructure is an infrastructure that deals with the development of people and the environment such as housing, health, education, and recreation. (3) Administrative infrastructure is an infrastructure in the form of law enforcement, administrative control, and infrastructure coordination.

\section{RESEARCH METHODS}

This type of research is quantitative descriptive research in research using data in the form of numbers which are processed using analytical tools. The output results will be explained using descriptive analysis both according to theory and deviate from existing theories. This study uses panel data which is a combination of annual time series data, from 2011 to 2017 and cross-section data from six provinces in Java. Data on domestic investment, foreign investment, labor, and clean water infrastructure of the six provinces in Java use data released by the Central Statistics Agency through the publication of Statistics Indonesia. The data analysis method used in the study is to describe the factors that influence the problem that is used as a supporter of the results of panel data regression.

The object under study was in this study the variables used consisted of the dependent variable and the independent variable. The dependent variable (Y) economic growth and the independent variable (X) consisted of domestic investment, foreign investment, number of workers, and water infrastructure clean. This research was conducted in all provinces in Java Island (DKI Jakarta, West Java, Central Java, Special Region of Yogyakarta, East Java, and Banten). The type of data used is secondary data which is panel data. Panel data is a combination of crosssection data with time series data.

According to Widarjono (2013) panel data is a combination of cross-section data with time series data that can be seen from the 
dependent variable consisting of several regions (cross-section) but in various time series (time series).

The model used to determine the effect of Independent Variables on Independent Variables in this study uses the natural logarithmic model (Ln). This research model before using the natural logarithm model (Ln) as follows:

PDRBit $=\beta 0+\beta_{1}$ PMDNit $+\beta_{2}$ PMLNit + $\beta_{3}$ TKit $+\beta_{4}$ AIRit $+\mu$ it.

According to Gujarati (2013) that the natural logarithmic model (Ln) has the advantage that is, to equalize the unit and minimize the possibility of heteroskedasticity due to transformations that place the measurement scale of variables and the slope coefficient $\beta i$ can directly show the elasticity of $\mathrm{Y}$ to $\mathrm{Xi}$ ie the percentage change in $\mathrm{Y}$ due to the percentage change in $\mathrm{Xi}$. After using the natural logarithm model ( $\mathrm{Ln})$, the model in this study is as follows:

$\operatorname{lnPDRBit}=\beta 0+\beta_{1} \ln P M D N i t+\beta_{2} \ln P M L N i t+$ $\beta_{3} \ln$ TKit $+\beta_{4} \ln$ AIRit $+\mu$ it.

Information :

lnPDRB : Logarithms of Natural PDRB

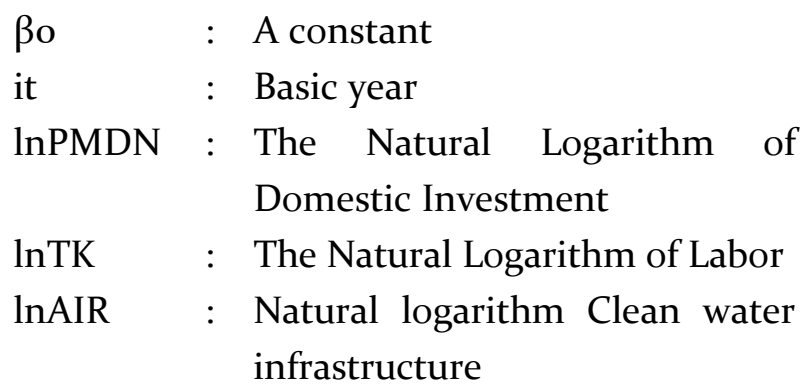

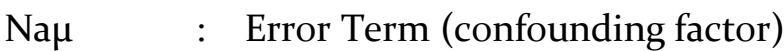

According to Gujarati (2015) panel data does not have to be a classic assumption test, this is because panel data has the following assumptions:

1. Regression parameters do not bear fruit over time

2. Variance error and function are homoscedatic

3. Error regression function from time to time is not related.

In the panel data, there are three models, namely the common effect model, the fixed effect model, and the random effect model. There are several methods in choosing the best model in the panel data including Chowtest and Hausman Test. Chow test is used to test the suitability of the model that is the model obtained with least squares panel data with the model obtained using the fixed effect method while the best test model is obtained from the results of the hausman test obtained from the random effect model.

\section{RESULTS AND DISCUSSION}

To estimate the effect of domestic investment, foreign investment, labor, and clean water infrastructure on the economic growth of Java in 2011-2017, it is necessary to select the best model to be selected in this study using the chow test and the thirst test.

In the Chowini test there are two models to choose from, namely the common effect and fixed effect models. If the result of the ChiSquared probability is greater than 0.05 then the common effect model is chosen whereas, if the Chi-Squared probability is less than 0.05 then the model chosen is the fixed effect 
model. Based on the data processing, the chow test results are as follows:

Table 3. Chow Test Results

\begin{tabular}{|c|c|c|c|}
\hline TestiSum & Chi- & Chi- & $\overline{\mathrm{P}}$ \\
\hline mary & \multicolumn{2}{|c|}{ Sq.Statistic Sq.d.f. } & rob.i \\
\hline Cross- & 15.127 & & o \\
\hline section random & 1591 & 4 & .0044 \\
\hline
\end{tabular}

Based on the results of the table above, it can be seen that the Chi-square cross-section probability value of o.oooo, which means less than 0.05 , it can be decided that Ho is rejected and $\mathrm{H}_{1}$ is accepted. Hausman test.

Hausman test is used to choose the model that should be used whether fixed effect or random effect. If the result of the ChiSquare probability is greater than 0.05 then the random effect model is used whereas, if the Chi-Square probability is smaller than 0.05 the model used is the fixed effect. Based on the data processing carried out the following hausman test results:

Table 4. Hausman Test Results

\begin{tabular}{ll}
\hline Test Summary & $\begin{array}{l}\text { Chi- } \\
\text { Sq.Statis Chi-Sq.d.f. Prob. } \\
\text { tic }\end{array}$ \\
\hline
\end{tabular}

\section{Cross-}

section random $15.1275914 \quad 0.0044$

Source: Data processing results using E-Views 9

Based on the table above, it can be seen that the probability of random Cross-section is 0.0044 , which means it is smaller than 0.05 so the model that should be chosen is the fixed effect model.

Table 5 Fixed Effect Model Estimation Results for the General Least Square (GLS) Method

\begin{tabular}{lccc}
\hline Variable & Coefficient & t-Statistic & Prob. \\
\hline C & -0.898031 & -2.950055 & 0.0059 \\
LNPMDN & 0.084265 & 5.475538 & 0.0000 \\
LNPMLN & 0.014668 & 1.459846 & 0.1541 \\
LNTK & 0.734333 & 26.66312 & 0.0000 \\
LNAIR & 0.134779 & 4.728570 & 0.0000 \\
Effects Specification & & & \\
Cross-section fixed (dummy variables) & & \\
R-squared & 0.999166 & & \\
Prob(F-statistic) & 0.000000 & &
\end{tabular}


Based on table 5, the following model is obtained:

$\ln \mathrm{PDRB}=-0.898031+0.084265 \ln \mathrm{PMDN}+$ $0.014668 \ln P M L N+0.734333 \ln T K+0.134779 \ln A I R$ $+\mu \mathrm{it}$

Information :

lnPDRB : Logarithms of Natural PDRB

Bo : A constant

it : Basic year

lnPMDN : The Natural Logarithm of Domestic Investment

lnTK : The Natural Logarithm of Labor

lnAIR : Natural logarithm Clean water infrastructure

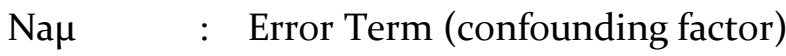

The Effect of Domestic Investment on Economic Growth

Based on the results of regression analysis using the fixed effect model, that domestic investment individually has a significant effect and has a positive relationship on economic growth with a statistical value $>\mathrm{t}$ table $(5.475538>1.685954)$ and a probability value of 0.0000 . Regression coefficient of 0.084265 which means that if domestic investment rises by $1 \%$, it can increase the economic growth of Java by $0.084 \%$ with the assumption of ceteris paribus.

This research is in line with the results of research conducted by Putri (2014) and Rizky, et al (2016) that domestic investment has a significant influence and has a positive relationship on economic growth. Java as an economic center in Indonesia certainly has high economic activity with adequate facilities and infrastructure compared to the other five islands and has the largest population in Indonesia, so this has become an attraction for investors to invest in Java.

Domestic investment is an important thing for each region in carrying out economic development. This is because investment has an important role in driving the regional economy, where with the existence of investment, adding capital in Java with higher investment will encourage economic growth in Java.

The results of this study are also in line with the theory put forward by Harrod-Domar. Referring to Harrod-Domar's economic growth, capital formation is seen as expenditure which will increase the effective demand of the whole community. HarrodDomar's theory shows that the fact that is ignored in the Keynesian analysis is that if a certain period of capital formation is carried out then the next time the economy has the ability to produce goods.According to the Harrod Domar growth model to spur economic growth a new investment is needed which is a net addition to the capital stock, so any additional net of capital stock in the form of new investment will increase the flow of national output or GNP. An economy in order to grow rapidly, it must save and invest a portion of its GNP.

Whereas in Prasetyo (2009) HarrodDomar argues that in the long run, investment (I) will increase the stock of capital such as roads, machinery, factories, etc. so that $\mathrm{I}=\Delta \mathrm{K}$, where $K$ is the stock of capital for the community. This increase in capital stock also means an increase in the community's production capacity. According to Mankiw 
(2006) investment refers to spending on business expansion and new equipment and things that can add to the capital stock. While the capital stock is an important determinant of economic output because the capital stock can change over time and the change can lead to economic growth.

Sukirno (2005) argues that investment activities enable the community to continue to increase economic activities and employment opportunities, increase national income and improve the level of prosperity of the community. There are three important functions of investment, namely investment is one of the components of aggregate expenditure so that an increase in investment will increase aggregate demand, national income and employment opportunities. Second, the increase in capital goods as a result of investment will increase production capacity. Third, investment is always followed by technological developments.

This study is not in line with research conducted by Rusydi (2011) found that domestic investment had no significant effect and had a positive relationship on economic growth and Marlina (2018) found that investment in the country had no significant effect and had a negative relationship on economic growth.

\section{The Effect of Foreign Investment on Economic Growth}

Based on the results of the regression analysis using the fixed effect model, that individual foreign investment had no significant effect on economic growth with a statistical value $<$ t table $(1.459846$ $<1.685954$ ) and a probability value of 0.1541 .
This study is in line with the results of research conducted by Marlina (2018) that foreign investment has no significant effect and has a positive relationship on economic growth. Foreign investment does not have a significant effect on economic growth because first, foreign investment in Indonesia is still hampered by the processing of permits which are still convoluted.

Second, based on the publication of the 2017 Investment Coordinating Board (BKPM) that foreign investment entering Indonesia is still dominant in the tertiary or service sector, where the tertiary sector contributes $42.3 \%$ while for the primary sector contributes $18.0 \%$ and the sector secondary contributing 39.7\%. These investments are not in accordance with what is needed by Indonesia such as laborintensive investment in the secondary sector. Third, increasingly intense competition in attracting investors in both developing and developed countries.

The results of this study are also in line with Keynes's opinion that the level of the economy is not determined by capital formation even the role of investment or capital formation is in theory ignored.

This study is not in line with research conducted by Putri (2014), Fadhila and Mahmoud (2015), and Rizky, et al (2016) that foreign investment has a significant effect and has a positive relationship on economic growth.

\section{The Effect of Labor on Economic Growth}

Based on the results of regression analysis using the fixed effect model, that individual workforce has a significant effect and has a positive relationship on economic growth with a statistical value $\mathrm{t}$ table $(26.66312>1.685954)$ and a probability value 
amounting to o.oooo. The coefficient value is 0.73433 which means that if labor increases by $1 \%$ it can increase the economic growth of Java Island by $0.734 \%$ with the assumption of ceteris paribus.

This study is in line with the results of research conducted by Norlita (2018), Anochiwa and Maduka (2014), Sari, et al (2016), and Eigbiremolen and Anaduaka (2014) who found that labor has a significant influence on economic growth. Increasing the quantity and high quality of labor is one of the positive driving factors in spurring economic growth in Java. An increase in labor quantity will add to the factor of production thereby increasing output and then this will increase income even greater.

The number of workers indirectly illustrates the number of jobs available so that the greater the number of jobs the more workers will be absorbed. Increasing the workforce followed by employment opportunities can encourage investment which will ultimately encourage regional economic growth. In addition, this study is also in line with the theory put forward by Adam Smith argues that human beings are the main production factors in determining the prosperity of a country. This is because, natural wealth is meaningless if there are no human resources to manage it so that it can benefit life.

Adam Smith believes that the allocation of human resources as a necessary condition in economic growth. Adam Smith also believes that population growth can encourage economic development, can also be an indication of the expansion of the market and the fulfillment of labor needs and followed by an increase in energy specialization that encourages productivity and technological innovation (Sukirno, 2011).

According to Todaro (200o) that the actual positive or negative effects of population growth depends on how the ability of an economy can absorb labor and employ each additional workforce. The results of this study are not in line with research conducted by Mokodompis, et al (2015) that labor has a significant effect and has a negative relationship on economic growth and Anwar, et al (2013) who find that labor has no significant effect and has a negative relationship on economic growth.

\section{Effect of Water Infrastructure on Economic Growth}

Based on the results of regression analysis using the fixed effect model that individual water infrastructure has a significant effect and has a positive relationship on economic growth with a statistical value $>\mathrm{t}$ table $(4.728570>1.685954)$ and a probability value of 0.0000 . The coefficient value is 0.134779 which means that if the clean water infrastructure increases by $1 \%$, it can increase economic growth in Java by $0.134 \%$.

This study is in line with the results of research conducted by Rusmusi and Handayani (2018) that clean water has a significant influence and has a positive relationship to economic growth. The availability of clean water infrastructure has an important role in the economy because the production process cannot be separated from clean water. Increased distribution of clean water shows the increasing need for clean water that must be met either for consumption 
or used for the production process where this can encourage increased economic growth.

This result is in accordance with the theory put forward by Sollow-Swan that in increasing economic growth, it is necessary to have a stock of capital where the intended stock of capital is not only the stock of human capital but also the stock of physical capital. The intended physical capital stock is infrastructure.

In improving the economy, it must be complemented with various supporting investments, namely infrastructure investment such as roads, electricity supply, water supply and sanitation improvements, communication network development (Todaro, 200o). Where one of the economic infrastructure according to the World Bank is the infrastructure used as economic infrastructure is clean water infrastructure.

The results of this study are not in line with the research conducted by Dewi and Gusni (2019) that clean water infrastructure has no significant effect and has a negative relationship on economic growth.

\section{CONCLUSION}

Based on the results of the study it can be concluded as follows; Domestic investment has a significant effect and has a positive relationship on economic growth in Java. Java Island as an economic center in Indonesia certainly has high economic activity with adequate facilities and infrastructure and has the largest population in Indonesia so that this is an attraction for investors to invest in Java.

The existence of investment will increase capital in Java with higher investment will encourage economic growth in Java.
Foreign investment has no significant effect on economic growth in Java. This is because it is still hampered by permit management, investment entering Indonesia is still dominant in the tertiary or service sector and not yet labor intensive and increasingly intense competition in attracting investors

Labor has a significant effect and has a positive relationship on economic growth in Java. Increasing the quantity and high quality of labor is one of the positive driving factors in spurring economic growth in Java. Increasing the workforce followed by employment opportunities can encourage investment which will ultimately encourage regional economic growth.

Clean water infrastructure has a significant effect and has a positive relationship on economic growth in Java. The availability of clean water infrastructure has an important role in the economy because the production process cannot be separated from clean water. Increased distribution of clean water shows the increasingly high demand for clean water that must be met either for consumption or used for the production process where this can encourage increased economic growth.

Based on this research, the following suggestions are obtained; Regional governments are expected to increase domestic investment in Java by increasing the potential of their respective regions in order to attract investors so that investment disparities between provinces do not occur, so that other provinces also need to be invested in capital to offset the economic growth of other provinces.

Local governments are expected to be able to create conducive investment climate, facilitate licensing so that investors are easier 
to set up businesses, and investments are expected not only in the form of capitalintensive but more labor-intensive investment so that it can absorb labor.

The local government is expected to increase labor productivity by increasing the allocation of education funds so that the quality of the workforce increases, providing foreign language training and skills to the workforce. Besides that, the division of work is clearly in accordance with their expertise and skills.

The regional government should plan for a better allocation of clean water and implement it intensively to improve the efficiency of the use of clean water, improving water quality must always be maintained in order to reduce water pollution in order to increase community productivity.

\section{REFERENCES}

Anochiwa, L.I,\& A, Maduka. (2014). Human Capital,Infrastructure and Economic Growth in Nigeria : An Empirical Evidence. IOSR Journal of Electrical and Electronics Engineering, Volume 9, Issue 4, pp o1-o6.

Anwar, N., Mirdad, A. J., \& Pujianto, H. (2013). Influence of Infrastructure,Investment and Human Resource to the Regional Economics Growth. Economic Development departement , Vol. 67, No. 10.

Badan Pusat Statistik (2011-2018). Statistik Indonesia. Jakarta: BPS.

Bank, W. (1994). World Devlopment Report : Infrastructure for Development. New York: Oxford University Press.

Dewi, W. Nila.,\& Gusni. (2019). Pengaruh Infrastruktur Dasar dan Infrastruktur Sosial Terhadap Pertumbuhan Ekonomi Desa Tertinggal. E-Jurnal Ekonomi dan Bisnis Universitas Udayana , pp.171182.
Eigbiremolen, G. O., \& Anadwaka, U. S. (2015). Human Capital Development and Economic Growth : The Nigeria Experience. International Journal of

Academic Research in Business and Social Sciences, Vol. 4 No.4.

Fadhila, Mohammed Ameen. Mahmoud Khalid Almsafirb. 2015. The Role of FDI Inflows in Economic Growth in Malaysia (Time Series: 19752010). Kajang: Procedia Economics and Finance 13 (2015) 1558-1566.

Fikriah, \& Wulandari, M. (2015). Analisis Pengaruh Investasi Infrastruktur Publik Terhadap Pertumbuhan Ekonomi Di

Aceh. Jurnal Ekonomi dan Kebijakan Publik, Vol. 2, No. 1.

Gujarati, D. (2013). Dasar-Dasar Ekonometrika.Edisi Keenam. Jakarta: Erlangga.

Gujarati, D. (2015). Dasar-Dasar Ekonometrika.Buku II.Edisi Kelima. Jakarta: Salemba Empat.

Kalu, C.O., Onyinye, M.O. (2015). Domestic Private Investment and Economic Growth in Nigeria : Issues and Further Consideration. International Journal of Academic Research in Business and Social Sciences, Vol. 5 No.2.

Mankiw, N. G. (2006). Makroekonomi Edisi Keenam. Jakarta: Erlangga.

Marlina, S. (2018). Pengaruh Net Ekspor dan Investasi Terhadap Pertumbuhan Ekonomi Di Provinsi Sulawesi Selatan. Jurnal Economix , Vol. 6, No. 1

Mokodompis, R., Rumate, V., \& Maramis, M. (2015). Pengaruh Tingkat Investasi, dan Tenaga Kerja Terhadap Pertumbuhan Ekonomi (Studi Pada Kota Manado Tahun 2003-2012). IEP-FEB Unsrat Manado, Vol. 15, No.1.

Norlita, V. (2018). Pengaruh Investasi, Tenaga Kerja, dan Infrastruktur Terhadap Pertumbuhan Ekonomi Di Pulau Jawa Tahun 2006-2015. Jurnal Pendidikan dan Ekonomi , Vol. 7, No. 2.

Prasetyo, E. P. (2009). Fundamental Makroekonomi. Yogyakarta: Beta Offset Yogyakarta

Putri, P. I. (2014). Pengaruh Investasi,Tenaga kerja, Belanja Modal, dan Infrastruktur Terhadap Pertumbuhan Ekonomi Pulau Jawa. Journal of Economics and Policy, pp. 100-202.

Reza, F \& Widodo, T. (2013). The Impact of Education on Economic Growth in Indonesia. Journal of Indonesian Economy and Business, Vol. 28, No.1. 
Rizky, R. L., Agustin, G., \& Mukhlis, I. (2016). Pengaruh Penanaman Modal Asing, Penanaman Modal Dalam Negeri, dan Belanja Modal Terhadap Pertumbuhan Ekonomi Provinsi di Indonesia. Jurnal Ekonomi , Vol. 8, No. 1.

Rusmusi, IMP \& Handayani, D. R. (2018). Pengaruh Investasi Infrastruktur Jalan, Air Dan Pendidikan Terhadap Pertumbuhan Ekonomi Jawa Tengah Tahun 2011-2015. Jurnal Ekonomi,Bisnis, dan Akuntansi (JEBA), Vol. 20 No.o3.

Rusydi, M. (2011). Faktor-Faktor Yang Mempengaruhi Pertumbuhan Ekonomi Sulawesi Selatan. Jurnal Ilmu Ekonomi BALANCE , Vol. 17, No.1.

Sari, M., Syechalad, M. N., \& Majid, S. A. (2016). Pengaruh Investasi, Tenaga kerja, dan Pengeluaran Pemerintah Terhadap Pertumbuhan Ekonomi Di Indonesia. Jurnal Ekonomi dan Kebijakan Publik , Vol. 3, No. 2.
Sukirno, S. (2002). Makroekonomi Modern : Perkembangan Pemikiran Dari Klasik Hingga Keynesian Baru. Jakarta: Raja Grafindo Persada.

Sukirno, S. (2011). Makroekonomi Teori Pengantar, Edisi Ketiga. Jakarta: Rajawali Grafindo Persada.
Sukirno, S. (2005). $\quad$ Ekonomi Pembangunan,Proses,Masalah, dan Dasar Kebijakan. Jakarta: LPFEUI Jakarta.

Todaro, M. P. (200o). Pembangunan Ekonomi. Jakarta: Bumi Aksara

Todaro, M. P. (2004). Pembangunan Ekonomi di Dunia Ketiga. Jakarta: Erlangga.

Undang-Undang Republik Indonesia Nomor 25 Tahun 2007 tentang Penanaman Modal.2007.Jakarta: diperbanyak oleh Menteri Hukum dan Hak Asasi Manusia.

Widarjono, A. (2013). Ekonometrika Pengantar dan Aplikasinya : Disertai Panduan Eviews. Yogyakarta: UPP STIM YKPN. 